\title{
Studies on Effect of Dates of Planting on the Incidence of Diamond Back Moth Plutella xylostella (Linn.) in Cabbage under Manipur Agroclimatic Conditions
}

\author{
M. Vignesh ${ }^{1 *}$ and Ibohal $\operatorname{singh}^{2}$ \\ ${ }^{1}$ Department of Agricultural Entomology, University of Agriculture Sciences, \\ Dharwad- 580005, Karnataka, India \\ ${ }^{2}$ Entomology, Central Agricultural University, Imphal, Manipur, India \\ *Corresponding author
}

\begin{abstract}
Keywords
Brassica oleracea, Plutella xylostella, Dates of planting.

Article Info

Accepted:

29 September 2017

Available Online:

10 October 2017 that favours its development and multiplication of the pest are necessary. Of these, adjustment of sowing time is one of the most important practices to avoid pest infestation. By changing or carefully selecting the time when a crop is planted it may be possible to avoid the egg-laying period of a particular pest, get young plants well established to a tolerant stage before the attack occurs or even get a crop matured before certain pests become abundant. The present objective was undertaken to investigate the better transplanting time for the minimized damage due to DBM. The results of field studies shown that the planting dates had significant effect on the incidence of DBM. Early planted crops recorded significantly lower leaf damage than the late planted crops. The data revealed that the lowest DBM damage percentage of $14.23 \%$ was recorded on $19^{\text {th }}$ Dec. transplanted crop and highest leaf damage percentage of $41.46 \%$ on the crops transplanted on $9^{\text {th }} \mathrm{Feb}$. It was also observed that significantly higher yield was obtained in the early planted crop $\left(19^{\text {th }}\right.$ Dec. $)$ with a mean yield of 19.97 t/ha than the late planted crop $\left(7^{\text {th }} \mathrm{Feb}\right.$. and $29^{\text {th }} \mathrm{Jan}$.) which gave only 6.8 and $7.8 \mathrm{t} / \mathrm{ha}$ and no heads were marketable in either case.
\end{abstract}

\section{A B S T R A C T}

Cabbage is attacked by many insect pests. Among them Diamond back moth (DBM), Plutella xylostella is an important and economic pests of cruciferous crops in particularly cabbage. In order to control the pest economically and effectively certain studies of the pest such as its seasonal incidence, peak period, extent of damage, and the climatic factors

\section{Introduction}

Cole vegetables grown mostly in winter season occupy an important position in meeting the dietary requirements of most of the people all over the world. Among the winter vegetables, cabbage (Brassica oleracea var. capitata Linn.), a native of West Europe and the North Mediterranean region is a popular and extensively cultivated crop because of their nutritional and economical values for producer and consumer point of view, respectively. There are number of reasons for the low productivity of cabbage when manipur is considered among which diamondback moth Plutella xylostella Linn, causes major damage in all the stages. And most importantly Diamondback moth is the first species that has evolved resistance to Bacillus thuringiensis in open field populations (Heckel et al., 2001). The susceptibility of a crop to a pest is greatly 
influenced by the prevailing climatic conditions and agronomic practices of a region. In order to control the pest economically and effectively certain studies of the pest such as their seasonal incidence, peak period, extent of damage, the climatic factors that favour the development and multiplication of the pest are necessary. Of these, adjustment of sowing time is one of the most important practices to avoid pest infestation. By changing or carefully selecting the time when a crop is planted it may be possible to avoid the egg-laying period of a particular pest, get young plants well established to a tolerant stage before the attack occurs or even get a crop matured before certain pests become abundant. Considering these facts number of transplanting dates been checked in this study in order to find the right time which will help to form the IPM.

\section{Materials and Methods}

The experiment was laid out in randomized block design (RBD) with four replications. The crop was planted on six different dates of transplanting at 10 days interval. The plot size was 20 sq.m $(5 \mathrm{~m} \times 4 \mathrm{~m})$ and spacing was maintained at $40 \mathrm{~cm} \times 50 \mathrm{~cm}$.

\section{Dates of transplantings (2014-15)}

$19^{\text {th }}$ December

$29^{\text {th }}$ December

$8^{\text {th }}$ January

$18^{\text {th }}$ January

$28^{\text {th }}$ January

$7^{\text {th }}$ February

\section{Observations recorded}

The crop was observed regularly for the larval appearance of diamond back moth. The total number of leaves and number of infested leaves due to diamond back moth were counted on five randomly selected tagged plants from each plot. The observations were recorded at seven days interval from the planting till the day before harvest.

Leaf damage percentage is calculated using the following formula,

No. of infested leaves/5 plants

Leaf damage $(\%)=$---------- X 100

Total no. of leaves $/ 5$ plants

\section{Statistical analysis}

The data obtained from different experiments are computed to determine the mean values. The mean values after suitable transformation is subjected to statistical analysis to test significance as per the Analysis of Variance for interpretation of the results.

\section{Results and Discussion}

The leaf damage percentage data showed in Table 1 and illustrated in Fig. 1 revealed that there was a great deal of variation of diamond back moth incidence in different planting dates during the Rabi season of 2014-15.

The leaf damage percentage due to diamond back moth at different planting dates during Rabi 2014-15, presented in Table 1 further revealed that a marked variation was observed under different planting dates. In $19^{\text {th }}$ December planted crop, significantly lower percentage of leaf damage $(0-14.23 \%)$ was recorded, followed by $29^{\text {th }}$ December, $9^{\text {th }}$ January, 19 January, $29^{\text {th }}$ January and $7^{\text {th }}$ February, planting dates with a mean leaf damage percentage of 8.93-25.14, 14.6626.76, 16.63-29.25, 21.40-31.63, 25.6-41.46, respectively.

However, there was significant difference of diamond back moth attack among all the different planting dates. 


\section{Int.J.Curr.Microbiol.App.Sci (2017) 6(10): 4943-4947}

Table.1 Effect of different dates of planting on leaf damage due to diamond back moth and yield of cabbage during Rabi season of 2015-16

\begin{tabular}{|c|c|c|c|c|c|c|c|c|}
\hline \multirow{2}{*}{$\begin{array}{l}\text { Treatments(Diffe } \\
\text { rent Dates of } \\
\text { plantings) }\end{array}$} & \multicolumn{7}{|c|}{ Leaf damage in percentages (\%) } & \multirow{2}{*}{$\begin{array}{l}\text { Mean yield } \\
(\mathrm{t} / \mathrm{ha})\end{array}$} \\
\hline & $19 \mathrm{Feb}$ & $26 \mathrm{Feb}$ & 5 March & 12 March & 19 March & 26 March & 2 April & \\
\hline $\begin{array}{l}\text { T1 (19 } \\
\text { December) }\end{array}$ & 0 & $2.7(9.46)$ & $1.5(7.03)$ & $1.27(6.55)$ & $4.77(12.52)$ & $11.56(19.91)$ & $14.23(22.14)$ & 19.97 \\
\hline $\begin{array}{l}\text { T2 (29 } \\
\text { December) }\end{array}$ & 8.93(17.36) & $14.86(22.63)$ & $4.73(12.52)$ & $3.03(10.47)$ & $15.21(22.95)$ & $21.71(27.69)$ & $25.14(30.07)$ & 17.99 \\
\hline T3 (09 January) & $14.66(22.46)$ & $17.51(24.73)$ & $8.13(16.54)$ & $4.03(11.54)$ & $23.35(28.86)$ & $22.95(28.59)$ & $26.76(31.11)$ & 14.58 \\
\hline T4 (19 January) & $16.63(24.04)$ & $19.6(26.28)$ & $8.83(17.26)$ & $6.9(15.23)$ & $23.82(29.2)$ & $27.28(31.44)$ & $29.25(32.71)$ & 10.19 \\
\hline T5 (29 January) & $21.40(27.56)$ & $12.33(20.53)$ & $9.86(18.24)$ & $8.23(16.64)$ & $14.15(22.06)$ & $27.88(31.82)$ & $31.63(34.2)$ & 7.805 \\
\hline T6 (07 February) & $25.6(30.4)$ & $31.34(34.02)$ & $17.46(24.58)$ & $15.71(23.34)$ & $42.95(40.92)$ & $39.43(38.88)$ & $41.46(40.11)$ & 6.8 \\
\hline S.E.d \pm & 0.38 & 0.72 & 0.38 & 0.17 & 1.31 & 0.94 & 0.93 & 0.32 \\
\hline C.D $(\mathrm{P}=0.05)$ & 1.42 & 1.96 & 1.43 & 0.96 & 2.63 & 2.22 & 2.22 & 1.30 \\
\hline
\end{tabular}

Figures in parentheses are angular transformed values 
Fig.1 Graphical presentation of effect of different dates of planting on leaf damage due to diamond back moth

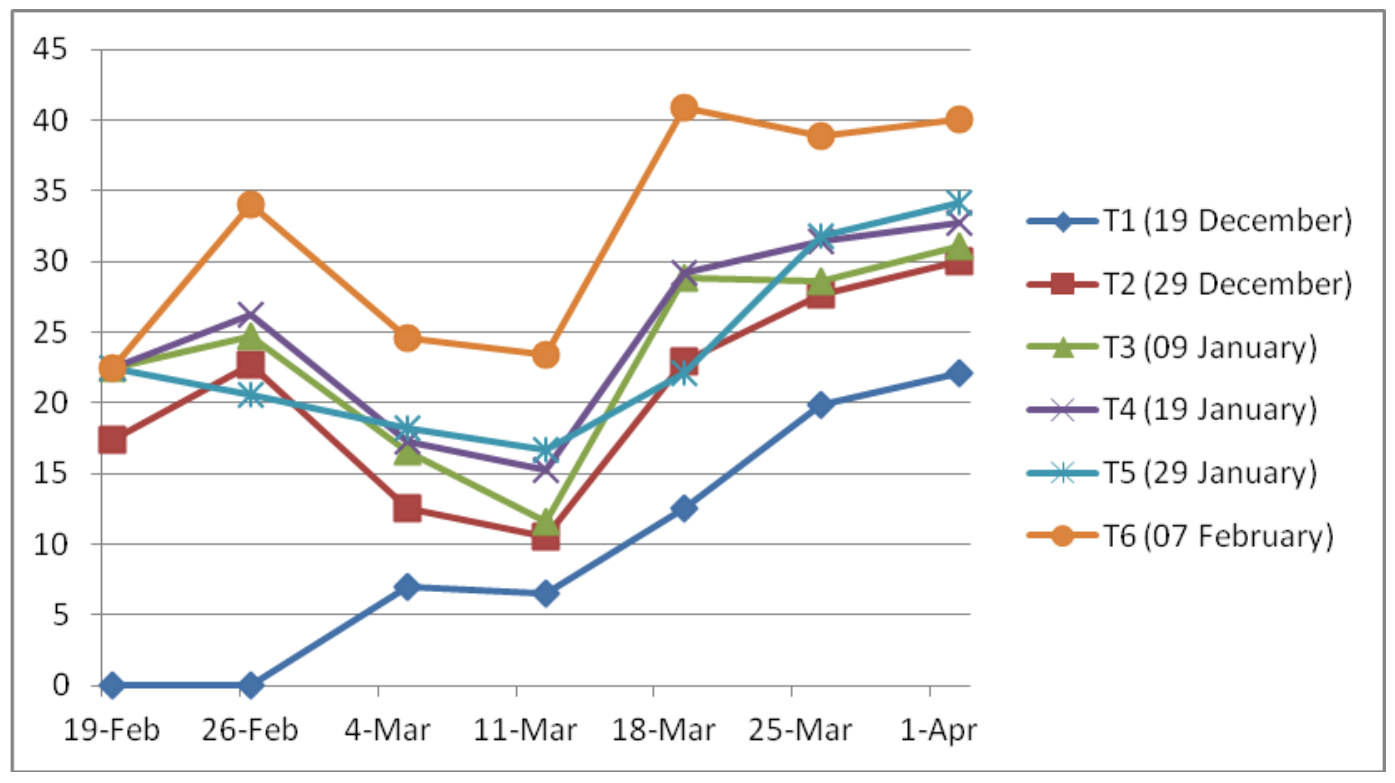

The data presented in Table 1 and illustrated in Fig. 1 revealed a significant variation effect between planting dates and diamond back moth degree of attack. The leaf damage percentage due to DBM just before harvest was lowest in $19^{\text {th }}$ December planted crop $(14.23 \%)$ whereas, significantly higher degree of leaf damage percentage was recorded in $7^{\text {th }}$ February planted crop with a leaf damage percentage of $41.46 \%$ just before harvest. It clearly revealed that the attack of DBM was low in the crop of early planting and the incidence of leaf damage is higher in the late plantings.

The mean yield indicated that the higher yield was obtained from the early planted crop. The maximum yield of $19.97 \mathrm{t} / \mathrm{ha}$ was harvested from $19^{\text {th }}$ December planted crop, followed by $17.99 \mathrm{t} / \mathrm{ha}, 14.58 \mathrm{t} / \mathrm{ha}, 10.19 \mathrm{t} / \mathrm{ha}, 7.805 \mathrm{t} / \mathrm{ha}$ and $6.8 \mathrm{t} /$ ha obtained from $29^{\text {th }}$ December, $9^{\text {th }}$ January, $19^{\text {th }}$ January, $29^{\text {th }}$ January and $7^{\text {th }}$ February planted crops, respectively.

Whereas significantly minimum cabbage yield of $6.8 \mathrm{t} / \mathrm{ha}$ was harvested from the crop planted on $7^{\text {th }}$ February.
In the present study, it was revealed that planting dates effected significantly on the incidence of DBM population. The crops planted on $19^{\text {th }}$ Dec. recorded significantly lower leaf damage due to DBM (0-14.23), whereas the late crops planted on $7^{\text {th }}$ Feb. recorded significantly higher leaf damage. A lower leaf damage in the early planted crop could be attributed to low initial population with subsequent slower rate of larval population build-up in the early part of the season. Further, the vulnerable stage of the crop (60-75 days after planting) coincided with favourable conditions for infestation in the late planted crops. Thus the present findings is in agreement with the results of Bana et al., 2012 studies in Jaipur who reported that the early planted crops registered less incidence of DBM.

The results indicates that the effect of different dates of planting on the yield of cabbage revealed that significantly higher yield was obtained in the early crops planted in $19^{\text {th }}$ Dec. and $29^{\text {th }}$ Dec. with a record of 19.97 and $17.99 \mathrm{t} / \mathrm{ha}$, respectively. While the late crops planted in $7^{\text {th }}$ Feb. and $21^{\text {th }}$ Jan. 
gave significantly lower yield with 6.8 and $7.8 \mathrm{t} / \mathrm{ha}$, respectively and there was no marketable heads in both the cases. This corroborate with the report of Bhoir and Patil (1999) that early planted crop (30 ${ }^{\text {th }}$ Nov.) gave maximum yield (19.38 t/ha), while late transplanted crop ( $30^{\text {th }}$ June) recorded lowest yield (8.77 t/ha). Viraktamath et al., (1994), also observed that the early crop planted in the $1^{\text {st }}$ week of Oct. gave the highest average yield per plot $(12.2 \mathrm{~kg})$, while in the late crops planted in $1^{\text {st }}$ week of Jan. and $1^{\text {st }}$ week of Dec., the percentage of leaf damage was very high and no heads were marketable in either case and these observations are in agreement with the present findings.

The planting dates had significant effect on the incidence of DBM. Early planted crops recorded significantly lower leaf damage than in the late planted crops. The data revealed that the lowest DBM damage percentage of $14.23 \%$ was recorded on $19^{\text {th }}$ Dec. transplanted crop and highest leaf damage percentage of $41.46 \%$ on the crops transplanted on $9^{\text {th }} \mathrm{Feb}$.

It was also observed that significantly higher yield was obtained in the early planted crop $\left(19^{\text {th }}\right.$ Dec.) with a mean yield of $19.97 \mathrm{t} / \mathrm{ha}$ than the late planted crop $\left(7^{\text {th }}\right.$ Feb. and $29^{\text {th }}$ Jan.) which gave only 6.8 and $7.8 \mathrm{t} / \mathrm{ha}$ and no heads were marketable in either case.

\section{References}

Bana, J.K., Jat B.L. and Bajya, D.R.,2012,Impact of transplanting dates on incidence of major insectpests of Cabbage, Ann. Pl. Protec. Sci. 20 (2) : 348-350.

Bhoir, P.M. and Patil, R.S. (1999). Varietal reaction of cabbage and impact of dates of transplanting on incidence of diamond back moth. J. Maharashtra Agril. Univ. 24(2):166-169.

Heckel, D.G., Tabashnik, B.E., Liu, Y.B., Gahan, L.J., Anthony, M., Zhao, J. and Baxte, S.W., 2001, Diamondback moth resistance to Bt: relevance of genetics and molecular biology to detection and management Proceedings of the 4th International Workshop, Nov. 2001, Melbourne, Australia.pp.1-10.

Viraktamath, S., Shekarappa, Reddy, B.S., and Patil, M.G. (1994). Effect of date of planting on the extent of damage by the diamond back moth, Plutella xylostella on cabbage. Karnataka J. Agric. Sci., 7(2):238-239.

\section{How to cite this article:}

Vignesh, M. and Ibohal singh. 2017. Studies on Effect of Dates of Planting on the Incidence of Diamond Back Moth Plutella xylostella (Linn.) in Cabbage under Manipur Agroclimatic Conditions. Int.J.Curr.Microbiol.App.Sci. 6(10): 4943-4947. doi: https://doi.org/10.20546/ijcmas.2017.610.467 